\title{
Role and significance of legal customs in national jurisdictions (in terms of the Russian Federation)
}

Papel y significado de las costumbres legales en las jurisdicciones nacionales (en términos de la Federación Rusa)

Papel e importância dos costumes legais nas jurisdições nacionais (em termos da Federação Russa)

\author{
Aleksey Pavlovich Anisimov ${ }^{1}$ \\ Anatoliy Jakovlevich Ryzhenkov ${ }^{2}$ \\ Lyudmila Viktorovna Sokolskaya ${ }^{3}$
}

Received: August 15 $5^{\text {th }}, 2021$

Accepted: October $18^{\text {th }}, 2021$

Published: December 24 ${ }^{\text {th }}, 2021$

How to cite this article:

Aleksey Pavlovich Anisimov, Anatoliy Jakovlevich Ryzhenkov \& Lyudmila Viktorovna Sokolskaya. Role and significance of legal customs in national jurisdictions (in terms of the Russian Federation). DIXI, vol. 24, nº. 1, enero-junio 2022, 1-22. DOI: https://doi.org/10.16925/2357-5891.2022.01.09

Research article. https://doi.org/10.16925/2357-5891.2022.01.09

1 Professor at the Department of Civil and International Private Law, Volgograd State University. Doctor of Juridical Sciences.

E-mail: anisimovap@mail.ru

2 Professor at the Department of Civil Law and Procedure, Kalmyk State University. Doctor of Juridical Sciences.

E-mail: 4077778@list.ru

3 Associate Professor at the Department of Private Law, State Humanitarian Technological University. Candidate of Juridical Sciences, Associate Professor.

E-mail: cokol4512@yandex.ru 


\begin{abstract}
In the Russian legal science, there is an established opinion that today legal custom plays a secondary role in the system of sources of law, or even that it is a rudiment and is not required in regulation of social relations anyway. This position of scientists is explained by the fact that theories rejecting custom as a source of law were common in the USSR since the 1920s. There were numerous attempts to substantiate the impossibility and needlessness of its use in a socialist state. It was justified by the fact that custom is a "primitive" form of law that is not capable of efficiently regulating social relations and even hinders their development. Having studied the modern practice of application of customs in various branches of private and public law, the authors give reasons for the conclusion that the scope of legal customs still retains its significance in Russia. It is proved that the role of customs differs in respect of fields of private and public law, occupying an insignificant place within the latter. However, also in that case there is transformation of established ideas about legal customs, their position in the system of sources of law and the role in the system of legal regulation of social relations are revised. The authors of the article substantiate the need to preserve legal custom in the system of sources of law and propose measures to increase the efficiency of their use.
\end{abstract}

Key words: Business custom, forms of law, legal system, legal custom, rules of customary law, sources of law.

\title{
Resumen
}

En la ciencia jurídica rusa, existe una opinión consolidada de que hoy en día la costumbre jurídica desempeña un papel secundario en el sistema de fuentes del derecho, o incluso que es un rudimento y no es necesaria en la regulación de las relaciones sociales de todos modos. Esta posición de los científicos se explica por el hecho de que las teorías que rechazan la costumbre como fuente del derecho eran comunes en la unss desde los años veinte. Hubo numerosos intentos de fundamentar la imposibilidad y la innecesidad de su uso en un estado socialista. Se justificaba por el hecho de que la costumbre es una forma "primitiva" de derecho que no es capaz de regular eficazmente las relaciones sociales e incluso obstaculiza su desarrollo. Tras estudiar la práctica moderna de la aplicación de las costumbres en diversas ramas del derecho privado y público, los autores dan razones para concluir que el ámbito de las costumbres jurídicas sigue conservando su importancia en Rusia. Se demuestra que el papel de las costumbres difiere respecto a los campos del derecho privado y público, ocupando un lugar insignificante dentro de este último. Sin embargo, también en ese caso se transforman las ideas establecidas sobre las costumbres jurídicas, se revisa su posición en el sistema de fuentes del derecho y el papel en el sistema de regulación jurídica de las relaciones sociales. Los autores del artículo fundamentan la necesidad de preservar la costumbre jurídica en el sistema de fuentes del derecho y proponen medidas para aumentar la eficacia de su uso.

Palabras clave: Costumbre empresarial, formas de derecho, sistema jurídico, costumbre jurídica, normas de derecho consuetudinario, fuentes del derecho.

\section{Resumo}

Na ciência jurídica russa, há uma opinião estabelecida de que hoje o costume jurídico desempenha um papel secundário no sistema de fontes do direito, ou mesmo que é um rudimento e não é exigido na regulamentação das relações sociais de qualquer forma. Esta posição dos cientistas é explicada pelo fato de que as teorias que rejeitam o costume como fonte de direito eram comuns na uRss desde os anos 20 . Houve inúmeras tentativas para substanciar a impossibilidade e a ausência de necessidade de seu uso em um estado socialista. Justificava-se pelo fato de que o costume é uma forma "primitiva" de direito que não é capaz de regular eficientemente as relações sociais e até mesmo impede o seu desenvolvimento. Tendo estudado a prática moderna de aplicação dos costumes em vários ramos do direito privado e público, os autores dão razões para 
a conclusão de que o escopo dos costumes legais ainda mantém sua importância na Rússia. Está provado que o papel dos costumes difere em relação aos campos do direito privado e público, ocupando um lugar insignificante dentro destes últimos. Entretanto, também nesse caso há uma transformação das idéias estabelecidas sobre os costumes legais, sua posição no sistema de fontes do direito e o papel no sistema de regulamentação legal das relações sociais são revisados. Os autores do artigo fundamentam a necessidade de preservar os costumes legais no sistema de fontes de direito e propõem medidas para aumentar a eficiência de seu uso.

Palavras-chave: Costume empresarial, formas de direito, sistema jurídico, costume jurídico, regras do direito consuetudinário, fontes do direito.

\section{INTRODUCTION}

The legal meaning of custom is one of the most interesting and understudied issues both within the general theory of law and branch legal sciences. The peculiarity of legal customs is that they are not directly established by rules of law (in this case they lose their property of legal customs), however, rules of law can refer to them.

From history we know that even the ancient Romans said "optima legum interpres consuetudo" (custom is the best interpreter of laws), and according to the famous Russian proverb, "general rule is the same thing as the tsar's decree" (in the sense it is as mandatory as a decree of the tsar). The Soviet legal doctrine and practice paid insufficient attention to legal custom. It is explained by the fact that theories rejecting custom as a source of law were common in the 1920s; repeated attempts were made to substantiate the impossibility of use of customs by the socialist state. However, the collapse of the USSR and the formation of a democratic state in Russia led to revision of the established ideas about legal customs and their role in the system of legal regulation of public relations.

The authors' interest in the chosen topic is caused by the increasing role of custom as a form of law in domestic law of many Western European states, as well as in international law. Today, legal custom is recognized as a source of public and (or) private law in many states. Customs with a mediative basis are widely used for extrajudicial dispute resolution and conclusion of amicable agreements by parties. Courts are entitled to determine independently whether application of rules of customary law is acceptable in a particular case, though this makes the judicial procedure causal. The latter provision is quite relevant to courts of general jurisdiction of most countries of the world. Certainly, activity of Russian courts is based on application of regulatory legal acts. Judicial bodies themselves do not create any customs and not assign any status to them. Judges adopting decisions can use only a custom that has been already recognized as a form of law. Judges check the content of the 
custom, its knownness to parties, morality of its provisions, its compliance with regulatory legal acts. ${ }^{1}$

Hence, it follows that custom as a source of modern law is an essential element of the system of legal regulation of social relations, it is aimed at settlement and minimization of conflicts, and strengthening of law and order. This source of law is a product of society development. This product is formed and modified along with the society, being an important key to understanding its evolution. Consequently, this article can be useful for legal scholars interested in theory and history of Russian law, and for practicing lawyers, as well as businessmen running their business in the Russian Federation.

\section{GENERAL CHARACTERISTICS OF LEGAL CUSTOMS IN THE RUSSIAN LEGAL LITERATURE}

The Russian science understands legal custom as a regulatory system consolidating historically established customary rules of conduct use, which is ensured by the power of the state. In other words, it is a custom that has been officially approved (sanctioned) by the state. The following types of sanctioning are distinguished according to how state bodies include custom in the national system of sources of law: 1) Consolidation of a reference to a legal custom in a blanket rule by a legislative authority due to particular relations; 2) use of a custom by judicial authorities when considering cases without the legislator's permission (tacit authorization); 3) application of a certain order of settlement of cases by judicial authorities, which becomes permanent in the course of development of judicial practice. ${ }^{2}$

Legal customs are widely used in many national legal systems, at core being generally recognized or quite common standards, patterns, rules of human conduct, and means for regulation of their interaction which protect social life from chaos managing its course the right way. ${ }^{3}$ The following attributes of legal custom are usually distinguished based on its legal definition: 1) it is a rule of behavior; 2) its formation has been completed; 3 ) it is widely used in a particular area of activity; 4) it is not legislation. ${ }^{4}$

\footnotetext{
1 V. A. Rybakov. Legal custom: The past and the present. MODERN LAW 3. 2009. P. 14.

2 Ibidem. P. 13.

3 V. A. Ponomarenkov. Ethnosocial determination of legal customs. "BLACK HOLES" IN THE RUSSIAN LEGISLATION 3. 2005. P. 214.

4 N. V. Kozlova, S.Yu. Filippova. Custom in civil law. RUSSIAN LAW JournaL 1. 2019. P. 6272.
} 
There are various criteria for its classification, such as: 1) The scope and coverage of customary legal rules (international, federal, regional and local); 2) the nature of relations that are regulated by customary legal rules (legal customs with effect of a private nature and legal customs with effect of a public nature); 3) content of relations regulated by legal customs (trade customs, as well as legal customs in the field of criminal law, family, consular, diplomatic relations, etc.); 4) the correlation between legal custom and law (regulatory legal act) as a source of law (legal customs that serve as an "addition to law", legal customs that are "except law", and legal customs that are legal provisions "against the law" by their nature and content). ${ }^{5}$

Diversity of legal customs shows that they, having emerged in ancient times, have significantly evolved and have been preserved almost in all legal systems to the present day, "having influence on legal development, filling in gaps in areas of legal communication, as well as in cases where legal regulations are not viable". ${ }^{6}$ Certainly, the concept, attributes and types of legal customs are due to uniqueness of the historical path of society development (from ethnic groups to international communities), social, economic and cultural factors. Consequently, a small historical study should be conducted regarding emergence and development of legal customs in Russia.

Customs, as unwritten rules of conduct, organized relations between people even in the pre-state era, and served as the main means of regulating social relations during formation of ancient states. Exactly in this period the state power validates a common rule of conduct that has become permanent in a certain society. Therefore, legal custom becomes a material source of law from which the state draws the content of prescriptions of law. ${ }^{7}$ At all stages of development of the Russian state, from Ancient Russia to the Russian Federation, legal custom served and serves as a social regulator; however, its scope and the order of sanctioning by the state have changed considerably. In the Ancient Russian state, the legislator gradually tended to take control of application of customs, providing them with legal protection or narrowing the field of their application. Customs are enshrined in the form of collections (law books), primarily in order to facilitate performance of judicial functions.

Procedures in civil and criminal cases were regulated by sanctioned customs, but in unprecedented cases judges waited for instructions from princes or from the popular assembly. The unity of judicial investigative procedures was gradually

5 M. V. Zakharova. LEgAL CUSTOM AND MODERNIZATION IN LAW (CASE STUDY OF FRANCOPHONE AFRICA AND MADAGASCAR). Moscow State Law Academy. (2005). P. 1011.

7 Yu. Yu. Vyatkina. History of emergence and development of custom in Russian law. CURRENT ISSUES OF MODERN SCIENCE 33. 2014. P. 171. 
ensured by written sources (Russkaya Pravda, Pskov Judicial Charter of the 9th century, Novgorod Judicial Charter of 1475, Sudebnik of 1497, Council Code of 1649).

Development of Russian imperial law is characterized by dominance of legislative acts over legal custom and judicial practice in the field of public administration. The principle of priority of law over other sources of law is finally established in the field of public administration. However, the laws actually did not cover the field of civil legal relations. Application of legal custom was maintained among peasants to resolve domestic problems inside rural communities during the whole imperial period. Realizing the role and significance of legal custom among members of national minorities and peasant communities, the tsarist government created a Commission for study of people's legal customs under the Geographical Society in Saint Petersburg. The Programs prepared by the Society in 1864 and 1877 to collect people's customs made an invaluable contribution to the study of customary law. ${ }^{8}$

In the UssR, legal custom, as a conservative element of the past, was recognized as inappropriate to the new socialist way of life of Soviet people. Supporters of the Soviet legal doctrine considered custom as an obsolete and primitive form of law, which is not able to regulate social relations and also hinders their development. ${ }^{9}$ Though the Soviet power rejected legal custom as a source of Soviet law, however, it recognized its application in international private law.

The Russian legal system transforms as well along with the collapse of the USSR and the development of market relations. Many civil legal relations in the entrepreneurial field began to be regulated by legal customs and practices, ${ }^{10}$ due to the lack of a legislative framework in the period of transition to new economic relations and formation of private property ${ }^{11}$. This is why in 1994 the provision that business custom, that is a rule of conduct which has become permanent in any area of entrepreneurial activity, shall be the source of civil law was enshrined in the Civil Code of the Russian

8 PROGRAM FOR GATHERING PEOPLE'S JURIDICAL CUSTOMS / NOTES OF THE IMPERIAL RUSSIAN GEOGRAPHICAL SOCIETY IN THE DEPARTMENT OF ETHNOGRAPHY. Printing House of Kirschbaum. (1878). Volume 8. P. 5.

9 M. V. Kicha. CUSTOM AS A FORM OF LAW IN ANGLO-SAXON AND ROMANO-GERMANIC LEGAL FAMILIES: COMPARATIVE LEGAL STUDY. Russian State University of Justice. (2015). P. 4.

10 Practices means those established in commercial activity as well as in everyday life. A variety of legal customs that is not clearly enshrined in any document.

11 There was no private property in the USSR. Socialist ownership of means of production in the form of state (people's) and collective-farm cooperative ownership was the economic basis of the country (Art. 10 of the 1977 Constitution of the USSR). Art. 13 of the Constitution of the USSR enshrined availability of personal property of citizens. Ref.: Constitution (Fundamental Law) of the Union of Soviet Socialist Republics (adopted at the Seventh Special Session of the Supreme Council of the UssR Ninth Convocation on October 7, 1977), Legal Reference System "Garant". Available at: https://cutt.ly/5TCX$\mathrm{sEj}$ 
Federation. In 2012, "business custom" in Article 5 of the Civil Code of the Russian Federation was replaced with "legal custom". Therefore, the Civil Code considerably expanded the field of application of legal customs. Moreover, while legal customs were previously applied only when the possibility of their application was expressly mentioned in law, according to the current Civil Code of the Russian Federation legal customs are applied also when this is not stipulated by the legislation, irrespective of whether an established and widely applied rule of conduct is recorded in some document or not. 12

The small historical study allowed the authors of the article to formulate several preliminary conclusions that legal custom, as a source of law, is an integral element of the Russian legal system. It is established as a rule of conduct in relation to an indefinite range of persons and occupies a special place in the mechanism of legal regulation. It has passed a long way of development as a source of law in Russia. At the early stages, it served as the main regulator of social relations and sometimes did not require state sanctioning for an additional weight and importance, but it gradually loses its leading role as a source of law. The state takes control of regulation of social relations, sanctions social rules of conduct (mandatory and optional), and monitors their correct implementation. In modern Russia, only those customs that are recognized by the state power have legal force. However, the current situation leaves open the question of whether the existing field of application of custom is sufficient, whether it is necessary to expand (or, on the contrary, reduce) the possibilities of its application?

\section{EXPANSION OF THE FIELD OF APPLICATION OF LEGAL CUSTOMS IN MODERN RUSSIAN LAW}

Today, legal custom is officially recognized as a source of law, but not in all branches of Russian law. However, if it does not contradict law provisions, its application in the territory of the Russian Federation is acceptable. Let us consider use of legal customs in certain branches of Russian law.

In modern constitutional law, application of legal customs is enshrined in several articles. For example, according to P. 1, Article 131 of the Constitution of the Russian Federation, local governance in urban, rural settlements and other territories shall be implemented with consideration of historical and local traditions. Analysis of provisions of Article 33 of the Regulation of the State Duma of the Russian Federation

12 V. A. Rybakov, supra, note 4. P. 11-16. 
clearly demonstrates use of customs, prescribing opening of the first meeting of the Duma by the oldest deputy. ${ }^{13}$ Many peoples of Russia have similar customs. For example, the Komi (Zyryan) people has long had a custom with a community meeting opened by its oldest member. Today, the Constitution of the Komi Republic (P. 2, Article 72) enshrines the right of the oldest deputy to open the first meeting of the State Council of the Komi Republic.

Another not less striking example of legal customs consists in the fact that even in the Soviet times there was a legal custom to nominate only one candidate in elections to any councils of people's deputies. This tradition is well preserved also at the modern stage: The State Duma approves the only proposed Chairman of the Government of the Russian Federation; there is only one candidate for Prosecutor General of the Russian Federation approved by the Federation Council; representative bodies of subjects of the Russian Federation approved the only candidacy for governor proposed by the President of the Russian Federation until recently (now governors are elected again). Moreover, there is no law that stipulates exactly this "unambiguous" pattern of conduct.

In civil law, legal custom (business custom - as a civil legal variety of legal customs) gained official recognition in the Fundamentals of Civil Legislation of the Union of Soviet Socialist Republics and the Union Republics of May 31, 1991 that mentioned business customs (par. 2 of Article 59, pars. 2, 3 of Article 63, Article 64, par. 2 of Article 75), as well as the "international custom recognized by the ussR". Before adoption of this regulatory legal act, only "practice" was considered as a variety of customs, it was understood as a nonlegal custom effective in the field regulated by law.

The Civil Code of the Russian Federation initially enshrined the legal category "business custom", which was recognized as a source of law, in Article 5. In addition, according to the said Article, in order for an existing custom to become a business custom, there were four necessary requirements, which should be specified: 1) Rules of conduct must be established (become permanent); 2) rules of conduct must be applied widely rather than in a narrow sense; 3) rules of conduct must not be stipulated by the legislation; 4) rules of conduct must be socially useful and must not contradict the principles of society. ${ }^{14}$

The highest judicial instances of the Russian Federation also contributed to clarifying the essence of business customs, emphasizing that "business custom [...]

13 Regulation of the State Duma of the Federal Assembly of the Russian Federation (as amended), Legal Reference System "Garant". Available at: https://cutt.ly/fTCLmNw

14 A. R. Balasanyan. BUSINESS CUSTOM IN RAILWAY TRANSPORT OBLIGATIONS. St. Petersburg University of the Russian Interior Ministry. (2007). P. 11. 
arising out of entrepreneurial activity should be understood as a rule of conduct not stipulated by the legislation or an agreement but established, that is enough definite in its content, widely applied in any area of entrepreneurial activity, for example, traditions of fulfillment of some or other obligations, etc.". ${ }^{15}$ Moreover, business customs were applied in Russia, irrespective of whether they were recorded in some document or not. However, they could not contradict provisions of the legislation or the agreement binding on participants of the corresponding relationship.

Federal Law No. 302-FZ of December 30, 2012 introduced amendments to the title of Article 5 of the Civil Code. This innovation was aimed at unification of the legislation of the Russian Federation, in accordance with international standards, for elimination of the terminological confusion that existed in the current legislation in relation to entrepreneurial activity (the concepts "trade custom", "port custom", "business custom", etc., are used along with custom in this area).

The custom, which may be applied by the court in settlement of disputes under civil law by virtue of Article 5 of the Civil Code of the Russian Federation, should be now understood as a rule of conduct which has become permanent. That is enough definite in its content, widely applied, rather than stipulated by the legislation, in terms of establishment and exercise of civil rights and fulfillment of civil duties not only in entrepreneurial but also other activity. For example, when citizens determine the order of use of joint property, perform some or other obligations. Both customs recorded in some document (published in the press, set out in court decisions in particular cases involving similar circumstances, certified by the Chamber of Commerce and Industry of the Russian Federation), and those existing irrespective of such a record are subject to application. Moreover, existence of a custom shall be proved by the party that refers to it (Article 56 of the Civil Procedure Code of the Russian Federation, Article 65 of the Administrative Procedure Code of the Russian Federation). According to paragraph 2 of Article 5 of the Civil Code of the Russian Federation, customs contradicting the basic principles of the civil legislation, as well as the provisions of laws, other legal acts or an agreement binding on participants of the corresponding relationship, shall not be applied. ${ }^{16}$

15 Ref.: Resolution of the Plenum of the Supreme Court of the Russian Federation and the Plenum of the Supreme Commercial Court of the Russian Federation No. 6/8 of July 1, 1996. Supreme Court of the Russian Federation. On some issues associated with application of Part One of the Civil Code of the Russian Federation. BULLETIN OF THE SUPREME COMMERCIAL COURT OF THE RUSSIAN FEDERATION 9. 1996.

16 Resolution of the Plenum of the Supreme Court of the Russian Federation No. 25 of June 23, 2015 "On Application of Some Provisions of Section 1 of Part One of the Civil Code of the Russian Federation by Courts". Legal Reference System "Consultant Plus". 
The authors of this article believe that the latest version of Article 5 of the Civil Code of the Russian Federation expands the scope of legal customs, extending them not only to the entrepreneurial field as stipulated before. The fact of recognizing legal custom as a source of law and giving it a certain legal force is a positive aspect. In a range of articles of the Civil Code of the Russian Federation there are direct references to customs, if relations of the parties are not regulated by rules of the legislation and terms of the obligation binding on the parties. Such references are more often observed in Ch. 22 "Performance of Obligations" (Articles 309, 311, 314, 315, 316), Ch. 30 "Sale and Purchase" (Articles 474, 478, 508, 510, 513), Ch. 37 "Contract" (Article 721), Ch. 45 "Bank Account" (Article 848), Ch. 46 "Settlements" (Article 863, 867, 874), Ch. 51 "Commission" (Article 992, 998). There are several articles of the Civil Code of the Russian Federation that relate to law of obligations and reflect "normal requirements". In addition, in one case this term supplements the reference to customs (Articles 309, 478,992 ), in the other one it is used as an independent term (Articles 484, 485, 721).

However, since custom is recognized as a source of law by Article 5 of the Civil Code, its application should be considered possible also if there is no direct reference to the custom in the relevant legal rules, or if there is a gap in the legislation and in terms of an agreement entered into by the parties. Provisions of par. 2 of Article 5 of the Civil Code of the Russian Federation, which do not contain a direct indication of the correlation between custom and the discretionary rule, are supplemented with the rule of par. 5 of Article 421 of the Civil Code of the Russian Federation, according to which customs are applied to terms of agreements if they are not determined by the parties themselves or by the discretionary rule. Customs should also be taken into account during interpretation of terms of agreements.

Although legal custom is not a source of civil procedure law, nevertheless, Part 1 of Article 11 of the Civil Procedure Code of the Russian Federation states that the court considering and settling civil cases can adopt decisions based on business customs, but only in cases stipulated by regulatory legal acts. Therefore, in exceptional cases business customs can be applied by the courts of general jurisdiction. At the moment in Russia any party to a civil case is allowed to prove or reject existence of a particular custom with any evidence permitted by law. Today, courts of general jurisdiction can be guided by customs by virtue of a direct indication by law regarding distribution of inheritance, determination of amounts of payments for burial, settlement of cases of demolition of unauthorized structures, etc.

In family law, there is still the legal custom according to which, in the vast majority of cases involving judicial settlement of issues about residence of children with one of the divorced parents, the courts adopt decisions (other things being equal) on 
residence of children with their mothers rather than their fathers. We have not managed to find any official statistics about this fact, but practicing lawyers assert that in about $94-95 \%$ of cases of divorce the court orders that the child stay with the mother rather than with the father. It is due to the opinion widespread in Russian society that mothers have a stronger emotional connection with their children, they are more responsible and better prepared psychologically to raise babies. ${ }^{17}$

Meanwhile, the Family Code or other laws do not provide any grounds for formation of exactly such judicial practice. Moreover, by virtue of Article 19 of the Constitution of the Russian Federation, equal rights and freedoms of men and women and equal possibilities for their exercise are proclaimed in Russia. The principle of equality of spouses' rights in a family is also enshrined in Article 1 of the Family Code of the Russian Federation.

Another striking example of legal custom in family law is that a range of laws of subjects of the Russian Federation mention the necessity to register surnames, names and patronymics of children in civil registry offices, ${ }^{18}$ in accordance with the local customs and traditions. For example, Article 49 of the Family Code of the Republic of Tatarstan establishes the right of children's parents to add the words "uly" and "kyzy", for boys and girls respectively, to the children's patronymics on the basis of the national customs. This rule is enshrined in Article 19 of the Civil Code of the Russian Federation, which states that a citizen shall acquire and exercise rights and obligations under his/her own name, unless otherwise required by law or a national custom. Article 13 of the Family Code of the Russian Federation is a variety of the latter legal custom as well. According to this Article, the order and conditions under which marriage may be permitted before 16 years old as an exception, with consideration of particular circumstances, may be established by laws of subjects of the Russian Federation. Consequently, a required rule appears in a law of a subject of the Russian Federation only if there are required local customs related to the given issue in the subject of the Russian Federation.

Many scientists also register existence of legal custom within the framework of labor law. According to S.Yu. Golovina, the Labor Code of the Russian Federation does not stipulate a seal as a mandatory element of an employment contract - "neither Article 67 of the Labor Code of the Russian Federation, establishing requirements for the form of employment contracts, nor Article 57 of the Labor Code of the Russian

17 E. Boytsova. Five reasons for which children can be left with their fathers after a divorce. August 9, 2016. Available at: https://cutt.ly/ITCXheR

18 Civil registry offices (ZAGs in Russia) - bodies for civil status registration (Zapis Aktov Grazhdanskogo Sostoyaniya). These authorities record births, marriages and deaths. 
Federation listing the mandatory details of employment contracts do not mention an organization's seal". In this regard, she suggests consideration of a permanent custom involving certification of signatures of officers in employment contracts with the use of a seal. ${ }^{19}$ E.A. Ershova notes that in labor law:

[...]there has been long a custom formed as a result of many years of activity of employees and employers supported by the court and the prosecutor's office, according to which employees are reinstated in case of termination of the employment contract on their initiative due to a combination of adverse circumstances, if the employee files the application influenced by fraud, violence or threat. ${ }^{20}$

In land law, the following legal customs can be distinguished:

a) According to Article 23 of the Land Code of the Russian Federation, public easements may be established for haying, grazing farm animals on the land plots in the prescribed manner during the time period which complies with local conditions and customs.

b) According to par. 3, Article 13 of the Federal Law "On Turnover of Agricultural Lands" of July 24, 2002, if an owner of shared property allocates a land plot within his/her share, such a land plot may be formed on the basis of the decision of the general meeting of the owners of shared property, in case this decision approves the land plots demarcation plan, the list of owners of the formed land plots and their shares in the common ownership of the formed land plots. If a land plot is formed on the basis of the decision of the general meeting of the owners of shared property and according to the demarcation plan approved by this meeting, no additional agreement upon the size and location of the boundaries of the formed land plot is required. Despite the law does not expressly prescribe that the local conditions shall be observed during determination of the place of an allocated plot, this is what often happens.

c) According to Article 23 of the Civil Procedure Code of the Russian Federation, jurisdiction of justices of the peace includes cases involving determination

19 S. Yu. Golovina. "Blank spaces" of labor law. RUSSIAN YEARBOOK OF LABOR LAW 2. 2006. P. 146.

20 E. A. Ershova. SOURCES AND FORMS OF LABOR LAW IN THE RUSSIAN FEDERATION. MoscoW State Law Academy. (2008). P. 38-39. 
of the order of property use. Consequently, if there is a dispute about the order of use of a land plot (for example, between co-owners), this dispute may be resolved according to the local customs.

d) Erection of fences along the perimeter of plots exhibits properties of a legal custom. For example, the Land Code of the Russian Federation, the Federal Law of June 18, 2001 "On Land Management", other federal laws and bylaws do not mention exactly this way of exercise of the owners' authority to possess and limit the access to the land plot for third parties. From the perspective of establishing guarantees of rights of private owners (tenants) of land plots, it is quite sufficient to determine the area and boundaries of such a land plot by compiling its cadastral certificate. Consequently, construction of a fence around a plot (which, being made of bricks, acquires all attributes of immovable property) is a legal custom.

e) Legal custom plays a great role within individual national and combined national and religious communities. In this case, the most striking example is the indigenous and small-numbered peoples in relation to the land use of which a number of federal laws have been adopted: "On Guarantees of Rights of Indigenous Small-Numbered Peoples of the Russian Federation" of April 30, 1999; "On General Principles of Organization of Communities of Indigenous Small-Numbered Peoples of the North, Siberia and the Far East of the Russian Federation" of July 20, 2000; "On Territories of Traditional Nature Management of Indigenous Small-Numbered Peoples of the North, Siberia and the Far East of the Russian Federation" of May 7, 2001. For example, according to Article 13 of the latter law, use of natural resources located in territories of traditional nature management to ensure the traditional way of life shall be performed by persons belonging to such peoples and communities of small-numbered peoples, in compliance with the legislation of the Russian Federation, as well as customs of the smaII-numbered peoples.

Within natural resources law, there are sanctioned customs, that is, customs that have been included in law and, therefore, have become rules of law rather than customs. For example, people going to forests and gathering berries, mushrooms, nuts, etc., is a typical custom that has a centuries-old history. This legal custom became a rule of two branches of law at once. First, according to Article 221 of the Civil Code of the Russian Federation, in cases where gathering of berries, capture of fish and other aquatic biological resources, gathering or capture of other generally 
accessible things and animals are permitted in compliance with the law, the general permission given by the owner, or in compliance with the local custom in a certain territory, the right of ownership of the corresponding things shall be acquired by the person performing their gathering or capture.

A similar rule was enshrined in Article 21 of the 1997 Forest Code of the Russian Federation (no longer in force), stipulating the citizens' right to stay freely in the forest fund and in forests not included in the forest fund, unless otherwise stipulated by the legislation (public forest easement). The current Forest Code of the Russian Federation of December 4, 2006 (Article 11) also provides for the citizens' right to stay freely and free of charge in forests and prepare and gather wild fruits, berries, nuts, mushrooms, other edible forest resources (food forest resources), as well as non-timber forest resources for their own needs. Exceptions to the rule are possible, for example, in order to ensure fire safety.

In international law, legal custom serves as one of the main sources of law. As emphasized by legal scholars, ${ }^{21}$ such special features of international customs as the ability to fill in the gaps in contract law, to connect all the states of the international community, the ability to change according to changing needs of society and practice of states, bring to a conclusion that international custom within the system of international law prevails over international contract law in such areas as recognition of states, state integrity, and international legal responsibility. For example, in international environmental law, as rightly noted by V.M. Dikusar:

[...] in spite of the fact that contract quantitatively displaces international legal custom, the role of the latter cannot be diminished. With all drawbacks of custom (legal ambiguity, difficulties in law-enforcement practice, etc.), today it continues to play a significant role in international law relating to the environment, since it regulates relations between states that are not parties to some or other international agreements in the area of environmental protection. ${ }^{22}$

The Chamber of Commerce and Industry of the Russian Federation has certified that Incoterms 2010, ICc Rules for the Use of Domestic and International Trade Terms (Icc Publication No. 715), are a trade custom (business custom) accepted in

21 E. V. Ermakova. Legal custom as a form of enshrining legal rules in international law. BULLETIN OF SAMARA LAW INSTITUTE 2. 2012. P. 73-77.

22 V. M. Dikusar. INTERNATIONAL LEgAL ISSUES OF ENVIRONMENTAL PROTECTION. Institute of State and Law of the Russian Academy of Sciences. (2007). P. 8. 
Russia. ${ }^{23}$ Therefore, on the basis of the conducted research, we can draw a conclusion about real existence of legal custom in Russian jurisdiction. Customs occupy their own special place in each branch of law (there are many in private law, none in criminal law, the role of customs in other public branches of law is relatively small).

\section{PROBLEMS OF APPLICATION OF LEGAL CUSTOMS IN MODERN RUSSIA AND WAYS TO OVERCOME THEM}

A range of problems arises out of preservation and even expansion of the field of application of legal customs in law-making, law-enforcement and consultative activity. We should single out the following ones:

1. Lack of formal certainty and written establishment of most legal customs. Today, Article 5 of the Civil Code of the Russian Federation defines that, regarding its legal force, custom is inferior to provisions of regulatory acts and contractual terms. This determines their place in the system of sources of law - as additional sources (aimed at filling in the existing gaps) in the lower part of their hierarchical system. In the same article, the legislator states that record of a custom in some document is not required for its existence. It means that the legislator recognizes customs that are written and unwritten, enshrined and unenshrined at the official level as equally significant. This approach excludes their correlation according to the principle of hierarchy, that is, vertical interaction of these sources of law is not implied. Therefore, legal customs are not systematized or legalized by the state, for example, as a collection of rules. Recognizing customs as a source of civil law, the state does not establish a list of customs and a mechanism of their determination and application by courts and other executors of law. Meanwhile, today we observe intensive development of practice of entering into civil law contracts based on customary rules, as well as formation of corporate codes or sets of uniform customs and rules.

2. The legislation does not provide for particular requirements with which customs must comply as a source of law. For example, determination of

23 Resolution of the Board of the RF CCI No. 54-5 of June 28, 2012 "On Certification of the Trade Custom (Business Custom) Accepted in the Russian Federation", Legal Reference System "Consultant Plus". 
more clear criteria for classification of types of legal customs as a source of law in the legislation would be helpful. Today, Russian legislator actually distinguishes several types of legal customs: port customs of loading and unloading of vehicles (Article 129 of the Merchant Shipping Code of the Russian Federation), national customs (Article 19 of the Civil Code of the Russian Federation, Article 58 of the Family Code of the Russian Federation, and Article 18 of the Federal Law "On Civil Status Acts" of November 15, 1997), local customs (Article 221 of the Civil Code of the Russian Federation). Such classification and contradictions between national (ethnic) customs that are observed by parties to contracts or proceedings actually make it difficult for the party that refers to the custom to prove its existence and the necessity of its application (Article 56 of the Civil Procedure Code of the Russian Federation).

3. Unacceptability of use of some rules of customary law in the whole territory of Russia. It means that it is reasonable to apply a range of customary legal rules only in the territory of a certain region. For example, adats are not subject to application in the middle zone of Russia; customs of Siberia and the Far East should not be used in the North Caucasus, etc.

4. Uncertainty of sanctions for violation of rules of customary law.

5. Competition between international and national customs. For example, despite numerous references to "democracy" and "rule-of-law state" in the Constitution of Russia and the federal legislation, the thousand-year monarchical tradition actually left its imprint on the nature of activity of the President of the Russian Federation and the Presidential Executive Office. We hope that the same legal custom as in law of some other countries of the world will be formed in Russian constitutional law, under which the President of the country, having served two consecutive terms, having waited out the term of presidential office of his/her successor, and having served other two terms afterwards, will not run for the election in the future, though formally it is not prohibited by the Constitution of Russia.

6. In case of formation of a legal custom in public branches, the attitude of state authorities to it is often sharply negative. An example of such an attitude is long proceedings regarding refusal of a Muslim woman to be photographed for passport without a headscarf covering her hair. ${ }^{24}$ The legislator has an even more negative attitude to such a custom as a blood feud, which is 
confirmed by its recognition as a qualifying attribute of murder (Article 105 of the Criminal Code of the Russian Federation), as well as bride kidnapping. Regarding the latter, the Parliament of the Republic of Ingushetia asked to supplement the Criminal Code of the Russian Federation with a special set of elements (Article 126.1 "Kidnapping for the purpose of marriage"). ${ }^{25}$

7. In the modern judicial practice, references to customary law are applied rarely, though the key role is given to the court in cases of disputes about law, since it is the court that is vested with the right which is usually called "judicial discretion". Speaking about the issue of application of customs by courts when considering and resolving, for example, civil disputes, we should note that at the moment there are neither resolutions of the Plenum of the Supreme Court of the Russian Federation, nor judicial reviews expressing the legal position of courts regarding correct and uniform application of customs. This indicates uncertainty of the order of use of customs as a means of regulation of civil relations, which gives rise to a range of controversial issues in practice. We think that the established practice of application of customs by courts provides conditions for abuse of law as well as adoption of illegal and unjustified court decisions.

8. Lack of knowledge or misunderstanding of legal customs among practicing lawyers. This state of things is due to a range of causes, in particular: 1) A huge number of diverse customs; 2) the positivist type of legal understanding prevalent among practicing lawyers; 3) the failure of lawyers to study rules of customary law; 4) the gap between urban and rural ways of life, because most lawyers live and work in cities and customary law often implies a traditional lifestyle, etc. Some lawyers worry about the fact that Article 5 of the Civil Code of the Russian Federation allows application of ethnic customs which contradict the current legislation. However, it is necessary to specify that this rule relates only to private law and does not involve public law. Despite the problems set out above, customs have a powerful mediation resource. ${ }^{26}$

It was initially aimed at achievement of amicable settlement between the parties, without bringing the case to trial. Application of customs really greatly contributes

25 A bill on criminal liability for bride kidnapping introduced in the State Duma. Available at: https://cutt.ly/ITCLBwz

26 Harvey Peña-Sandoval. Mediación narrativa: técnicas y método para resolver conflictos en las organizaciones. DIXI 17-22. 2015. P. 25-36. 
to unburdening of courts (especially courts of general jurisdiction), and to significant reduction in the number of statements of claim submitted to them.

The said problems are subject to discussion. That is why we propose a range of provisions, implementation of which can facilitate their resolution:

1. Compilation of a collection (corpus) of customary law. This activity can be carried out both by various state and municipal authorities (including specially created committees, commissions, etc.), and by scholars - experts in the area of customary law and legal anthropology, theorists and historians of state and law, and it is quite acceptable to entrust record of rules of customary law to students of Law faculties.

2. Introduction of classification of customs into international, federal, regional and local. It is proposed that federal customs include those that have the most common nature and, correspondingly, can be applied in the entire territory of the Russian Federation. Regional customs can be used only in a certain region because they have distinctive national, territorial or some other peculiarities.

3. We share the position expressed in the scientific literature that if the legislator or the supreme judicial authority adopts a legal act regulating the procedure and conditions for application of customs, it will help to solve the problem and will facilitate reduction of cases of abuse of law. ${ }^{27}$

4. The increasing role of legal customs in the life of society and identification of different types of legal customs by the legislator allows us to formulate the following proposals for improvement of the legislation:

a) Provisions of Article 5 of the Civil Code of the Russian Federation must be brought into compliance with Article 421 of the Civil Code of the Russian Federation. Article 5 of the Civil Code of the Russian Federation must read as follows:

1. Custom shall be understood as a rule of conduct that has become permanent and widely applied in any area of entrepreneurial or other activity, and is not stipulated by the legislation, irrespective of whether it is recorded in some document or not. 2. Customs contradicting the

27 I. G. Khmelevskaya. Custom as a legal resource of formation of civil law: significance and practice of application. In: STATE THAT CREATES: LEGAL RESOURCES OF FORMATION. PROCEEDINGS OF THE INTERNATIONAL SCIENTIFIC AND PRACTICAL CONFERENCE. Belgorod State University. (2018). P. 310-313. Dedicated to the 25th anniversary of the Law Institute of the National Research University. 
provisions of the legislation of the agreement binding on participants of the corresponding relationship shall not be applied. 3. If the parties or a discretionary rule do not determine a term of the agreement, the corresponding terms shall be determined by customs applicable to the relations of the parties.

b) There is a need to supplement the Land Code of the Russian Federation with a rule referring to legal customs as a source of land law. In this regard, it appears necessary to supplement Article 2 of the Land Code of the Russian Federation with par. 5 as follows: "Legal customs, including business customs, may be applied to land relations unless it contradicts the essence of land relations, the legislation or the agreement".

c) In case of conflicts between rules establishing evaluative and collective categories, and during their application, centuries-old customary rules that do not contradict law, morality and other values should be taken into account. Customs initially emerged in the area of private law, because there are relations that require thorough legislative regulation to the least degree.

\section{CONCLUSION}

Legal customs were a source of law in history of law of many states of the world, including Russia at certain historical stages of development. They have a rich history of emergence, development and application. This form of law is very dynamic, and it is able to regulate rapidly changing social relations. Legal customs as a phenomenon of culture of different ethnic groups reflect perception of justice by a people, consequently, the state should take them into account and develop the most progressive of them. Customs are observed and supported by population of a particular region or a state, which contributes to their authority and facilitates active repeated application. Customary law is one of the conditions for successive and stable development of any state. The evolutionary nature of state development ensures continuity of the main social attitudes and institutions, which, in their turn, ensure functioning of customary law as part of the system of society at any stage of its development.

Today, we can point out the growing role of custom as a form of law in international and domestic legal regulation. Existence and effect of customary law as an independent system is recognized at the international level. However, in domestic regulation of social relations legal customs play a different role. 
For example, in the Russian legal system, legal customs occupy a place after the fundamental (general) principles of law, regulatory legal acts and regulatory legal contracts. Principles and rules of law contained in customary law have a subsidiary nature and are applied in case of emergence of gaps in law. In the Russian legal system, legal positivism prevails, that is why legal customs have a whole range of peculiarities. First, there is recognition of legal customs as such by the social legal consciousness in their basis. Second, legal customs are recognized as mandatory by the majority in certain social groups. Third, customs are mainly applied in the field of private law, where mass repetition of relations leads to emergence of established practices. Fourth, legal customs are rare in the Russian legal system and are not classified according to legal force or any other universal criteria. Fifth, the term "customary law" is not used by the legislator in Russian law at all.

From the analysis conducted above, it follows that nowadays in the Russian legal system customary law has powerful potential resources for further development and functions, both along with regulatory legal acts and as an addition to them, playing its own role. However, customs cannot be called legal without state sanctions, and it is impossible to assert that legal regulation in this case will be effective. Legal customs are a form of Russian law to the full extent, it is possible and necessary to refer to them, as well as to use rules consolidated by customs in law-enforcement (including judicial) activity. For the first time in Russian legal science, we brought together and systematized legal customs that have become permanent in most branches of Russian law, especially within branches of private law, having showed that they are not archaic in nature but living and "people's law" to a great extent.

Further development of the system of legal customs must be implemented on the basis of the following principles: Legal customs function when laws keep silence; customary law does not repeal laws, it can only weaken their effect if provisions of positive law are in conflict with people's beliefs; laws may abolish the custom that contradicts public order; the court applies customary law relying upon laws and judicial practice, but is guided by its own conviction in order to make a fair decision; a court decision contrary to a custom may be reviewed by a higher judicial instance. Strengthening of the value of customs, increasing of the volume of relations regulated by them and widespread application of customs as a form of law appear to be effective ways to resolve a number of problems. First of all, this contributes to significant unburdening of courts of general jurisdiction, which is confirmed by experience of a range of countries of the world. Application of customs helps to increase the level of legal awareness and legal culture of society and, partly, to reduce corruption if such behavior is not approved by the majority of population. 


\section{REFERENCES}

A. R. Balasanyan. BUsinesS CUSTOM In RAILWAY TRANSPORT OBLIGATIONS. St. Petersburg University of the Russian Interior Ministry. (2007).

E. A. Ershova. Sources and forms of Labor law in the Russian Federation. Moscow State Law Academy. (2008).

E. Boytsova. Five reasons for which children can be left with their fathers after a divorce. August 9, 2016. Available at: https://cutt.ly/ITCXheR

E. V. Ermakova. Legal custom as a form of enshrining legal rules in international law. BULLETIN OF SAMARA LAW INSTITUTE 2. 2012. P. 73-77.

Harvey Peña-Sandoval. Mediación narrativa: técnicas y método para resolver conflictos en las organizaciones. DIXI 17-22. 2015. P. 25-36.

I. G. Khmelevskaya. Custom as a legal resource of formation of civil law: significance and practice of application. In: State that CREATES: Legal ResourCes of Formation. ProceEdings Of THE International Scientific and Practical Conference. Belgorod State University. (2018). P. 310-313.

M. V. Kicha. Custom as a form of LAW in Anglo-Saxon And Romano-Germanic Legal families: COMPARATIVE LEGAL StUdy. Russian State University of Justice. (2015).

M. V. Zakharova. Legal CUSTOM AND MOdERNIZATION IN LAW (CASE STUdY OF FRANCOPHONE AfRICA AND MAdAGASCAR). Moscow State Law Academy. (2005).

N. N. Razumovich. Sources of law and form of law. Soviet StATE AND LAW 3. 1988.

N. V. Kozlova, S.Yu. Filippova. Custom in civil law. Russian LaW Journal 1. 2019.

Supreme Court of the Russian Federation. On some issues associated with application of Part One of the Civil Code of the Russian Federation. Bulletin OF THE SuPREME COMmERCIAL COURT OF THE RUSSIAN FEDERATION 9. 1996.

S. Yu. Golovina. "Blank spaces" of labor law. Russian YeARbook of LABOR LAW 2. 2006.

V. M. Dikusar. International LEgAL ISSUES OF ENVIRONMENTAL PROTECTION. Institute of State and Law of the Russian Academy of Sciences. (2007). 
22 Role and significance of legal customs in national jurisdictions (in terms of the Russian Federation)

V. A. Ponomarenkov. Ethnosocial determination of legal customs. "BLACK HOLES" IN THE RUSSIAN LEGISLATION 3. 2005.

V. A. Rybakov. Legal custom: The past and the present. MODERN LAW 3. 2009.

Yu. Yu. Vyatkina. History of emergence and development of custom in Russian law. CURRENT ISSUES of MOdern SCIENCE 33. 2014. 